\title{
High serum cholesterol levels in persons with 'high-normal' TSH levels: should one extend the definition of subclinical hypothyroidism?
}

Georgia Michalopoulou, Maria Alevizaki, Gregory Piperingos, Demetrios Mitsibounas, Emily Mantzos, Panayotis Adamopoulos and Demetrios A Koutras

Endocrine Unit, Department of Medical Therapeutics and Evgenidion Hospital, Athens University School of Medicine, Greece

(Correspondence should be addressed to D A Koutras, Department of Medical Therapeutics, Alexandra University Hospital, 80 Vasilissis Sofias Ave, 11528 Athens, Greece)

\begin{abstract}
Objective: The association between established hypothyroidism and high cholesterol levels is well known. The aim of the present study was to investigate the effect of thyroxine $\left(\mathrm{T}_{4}\right)$ administration on cholesterol levels in hypercholesterolemic subjects with TSH levels within the normal range ('highnormal' TSH compared with 'low-normal' TSH).

Design and Methods: We determined TSH levels in 110 consecutive patients referred for hypercholesterolemia (serum cholesterol $>7.5 \mathrm{mmol} / \mathrm{l})$. Those with 'high-normal' TSH $(2.0-4.0 \mu \mathrm{U} / \mathrm{ml}$ ) as well as those with 'low-normal' TSH $(0.40-1.99 \mu \mathrm{U} / \mathrm{ml})$ were randomly assigned to receive either 25 or $50 \mu \mathrm{g}$ $\mathrm{T}_{4}$ daily for two months. Thus, groups $\mathrm{A}$ and $\mathrm{B}$ (low-normal TSH) received 25 and $50 \mu \mathrm{g} \mathrm{T}$ respectively and groups $\mathrm{C}$ and $\mathrm{D}$ (high-normal TSH) received 25 and $50 \mu \mathrm{g} \mathrm{T}_{4}$ respectively. Serum $\mathrm{T}_{4}$, tri-iodothyronine $\left(\mathrm{T}_{3}\right)$, TSH, free thyroxine index, resin $\mathrm{T}_{3}$ uptake and thyroid autoantibodies (ThAab) as well as total cholesterol, high and low density lipoprotein cholesterol (HDL, LDL), and triglycerides were determined before and at the end of the two-month treatment period.

Results: TSH levels were reduced in all groups. The most striking effect was observed in group D (TSH levels before: $2.77 \pm 0.55$, after: $1.41 \pm 0.85 \mu \mathrm{U} / \mathrm{ml}, P<0.01$ ). Subjects in groups $C$ and $D$ had a higher probability of having positive ThAabs. A significant reduction in total cholesterol $(P<0.01)$ and LDL $(P<0.01)$ was observed after treatment only in group D. In those subjects in group D who were ThAab negative, there was no significant effect of thyroxine on cholesterol levels.

Conclusions: Subjects with high-normal TSH levels combined with ThAabs may, in fact, have subclinical hypothyroidism presenting with elevated cholesterol levels. It is possible that these patients might benefit from thyroxine administration.
\end{abstract}

European Journal of Endocrinology 138 141-145

\section{Introduction}

Hypothyroidism affects $0.5-2.4 \%$ of the population (1). In the first stages it may go unnoticed as the symptoms may proceed insidiously $(2,3)$. Before overt hypothyroidism is established, the only abnormality which may be detected is elevated serum thyrotropin (TSH). At this stage, when thyroid hormones are still in the normal range, the diagnosis of subclinical hypothyroidism is made. Several studies have shown that this disorder is quite common ( $10 \%$ in an elderly population) $(1,4)$. It is still a matter of controversy whether this disorder should be screened and treated (5).

During the last years several reports have shown that lipid abnormalities are encountered in this group of patients which may be attributed to 'impaired' thyroid function (6-8). We had previously observed that almost $10 \%$ of asymptomatic hypercholesterolemic patients have in fact subclinical hypothyroidism (9); in that study we had also observed that even TSH levels in the upper normal range may be associated with lipid abnormalities (9).

On many occasions it has been reported that normalization of the thyroid tests with thyroxine $\left(\mathrm{T}_{4}\right)$ administration was accompanied by improvement of the lipid abnormalities in the group with subclinical hypothyroidism (10). The aim of the present study was to investigate the effect of $\mathrm{T}_{4}$ administration on cholesterol levels in hypercholesterolemic subjects with TSH levels in the normal range ('high-normal' compared with 'low-normal').

\section{Patients and methods}

During the period of one year all patients who were referred for assessment of their lipid profile to the 
Preventive Medicine Unit of our Hospital were also examined for their thyroid function status. Of these, 110 consecutive patients who were found to have high cholesterol levels $(>7.5 \mathrm{mmol} / \mathrm{l})$ and TSH levels between $0.4-4.0 \mu \mathrm{IU} / \mathrm{ml}$ were included in this study. Further inclusion criteria were the absence of any other disorder or medication known to affect the lipid profile. All patients gave informed consent to participate in the study.

Patients were divided into two groups, one with TSH in the 'low-normal' range $(0.4-1.99 \mu \mathrm{U} / \mathrm{ml})$ and the other with TSH in the 'high-normal' range (2.0$4.0 \mu \mathrm{U} / \mathrm{ml}$ ). Patients were randomly assigned to receive either 25 or $50 \mu \mathrm{g}$ thyroxine/day for a period of two months.

Four groups were finally created according to the TSH levels and the daily $\mathrm{T}_{4}$ dose subsequently administered. Groups A $(n=35)$ and B $(n=25)$ both with lownormal TSH $(0.41-1.99 \mu \mathrm{U} / \mathrm{ml})$ received 25 and $50 \mu \mathrm{g}$ $\mathrm{T}_{4}$ respectively for two months. Groups $\mathrm{C}(n=24)$ and $\mathrm{D}(n=26)$ both with TSH in the high-normal range (2$4 \mu \mathrm{U} / \mathrm{ml}$ ) received 25 and $50 \mu \mathrm{g} \mathrm{T}_{4}$ respectively for two months. The age range and male/female sex ratio in each group were as follows: group A: $36-67$ years, 5/30; group B: $50-75$ years, $1 / 24$; group C: $35-75$ years, $2 / 22$; group D: 41-68 years, 1/25. Patients were asked not to modify their diet.

Serum $\mathrm{T}_{4}$, tri-iodothyronine $\left(\mathrm{T}_{3}\right)$, TSH, resin $\mathrm{T}_{3}$ uptake $\left(\mathrm{RT}_{3} \mathrm{U}\right)$, free thyroxine index (FTI) and thyroid autoantibodies (ThAabs) as well as total cholesterol, high and low density lipoprotein cholesterol (HDL, LDL) and triglycerides were determined before and at the end of the two-month treatment period. Blood samples were collected after a $12-14 \mathrm{~h}$ fast. Lipid levels were determined with an enzymatic colorimetric method using the reagents A-GENT purchased from Abbott Laboratories Ltd (Wokingham, Berks, UK) (normal range, cholesterol: $<6 \mathrm{nmol} / \mathrm{l}$; HDL: $>1.35 \mathrm{nmol} / \mathrm{l}$; LDL: $<3.9 \mathrm{nmol} / \mathrm{l}$; triglycerides: <150 g/l). TSH was determined by IRMA using the hsTSH coated tube assay, Ortho-Clinical Diagnostics (Amersham, Bucks, UK) (normal range, $0.4-4.0 \mu \mathrm{IU} / \mathrm{ml}$, intra- and interassay coefficients of variation 3.2 and $5.7 \%$ respectively). $\mathrm{T}_{4}$ and $\mathrm{T}_{3}$ levels were determined by RIA using the Amerlex-M $\mathrm{T}_{4}$ and $\mathrm{T}_{3}$ RIA kits, Johnson \& Johnson Clinical Diagnostics Ltd (Amersham, Bucks, UK) (normal range, $\left.\mathrm{T}_{4}: \quad 64.0-163.8 \mathrm{nmol} / \mathrm{l} ; \mathrm{T}_{3}: \quad 0.77-2.70 \mathrm{nmol} / \mathrm{l}\right) . \quad \mathrm{RT}_{3} \mathrm{U}$ levels were determined by an RIA developed in our laboratory (11), (normal range 25-35\%). The FTI was calculated from the $\mathrm{RT}_{3} \mathrm{U}$ according to the formula: $\mathrm{FTI}=\mathrm{T}_{4} \times \mathrm{RT}_{3} \mathrm{U} / 100$. Anti-thyroid peroxidase autoantibodies (anti-TPO) were measured by radioimmunoassay using the reagents AB-APO purchased from SorinBiomedica Diagnostics SpA (Saluggia, Italy) (normal levels $<10 \mathrm{IU} / \mathrm{ml}$ ). Anti-thyroglobulin autoantibodies (anti-Tg) were measured by IRMA using the reagents AB-HTGK-3 purchased from Sorin-Biomedica (normal levels $<100 \mathrm{IU} / \mathrm{ml}$ ).

Standard statistical methods included $t$-test, Wilcoxon matched-pairs signed ranks as appropriate, variance analysis, Mann-Whitney test and $\chi^{2}$.

\section{Results}

The mean values of the various parameters before and after treatment are shown in Tables 1 and 2. TSH levels were decreased significantly after thyroxine administration in all groups (Table 1). Total and LDL cholesterol

Table 1 Comparison of the various thyroid function test values before and after thyroxine administration ( $t$-test) in the four groups of patients.

\begin{tabular}{|c|c|c|c|c|c|c|c|c|}
\hline \multirow[b]{2}{*}{ Parameter } & \multirow[b]{2}{*}{ Group } & \multirow[b]{2}{*}{$n$} & \multicolumn{2}{|c|}{ Before } & \multicolumn{2}{|c|}{ After } & \multirow[b]{2}{*}{ t value } & \multirow{2}{*}{$\begin{array}{c}\text { Level of } \\
\text { significance }\end{array}$} \\
\hline & & & Mean & S.D. & Mean & S.D. & & \\
\hline $\mathrm{TSH}$ & $\begin{array}{l}A \\
B \\
C \\
D\end{array}$ & $\begin{array}{l}35 \\
25 \\
24 \\
26\end{array}$ & $\begin{array}{l}1.03 \\
0.95 \\
2.50 \\
2.77\end{array}$ & $\begin{array}{l}0.40 \\
0.49 \\
0.56 \\
0.55\end{array}$ & $\begin{array}{l}0.85 \\
0.67 \\
1.87 \\
1.41\end{array}$ & $\begin{array}{l}0.45 \\
0.64 \\
0.95 \\
0.85\end{array}$ & $\begin{array}{l}3.46 \\
2.10 \\
3.33 \\
7.55\end{array}$ & $\begin{array}{l}<0.01 \\
<0.05 \\
<0.01 \\
<0.01\end{array}$ \\
\hline $\mathrm{T}_{4}(\mathrm{nmol} / \mathrm{l})$ & $\begin{array}{l}A \\
B \\
C \\
D\end{array}$ & $\begin{array}{l}35 \\
25 \\
24 \\
26\end{array}$ & $\begin{array}{l}116.7 \\
119.0 \\
105.0 \\
111.7\end{array}$ & $\begin{array}{l}23.4 \\
17.8 \\
21.2 \\
21.1\end{array}$ & $\begin{array}{l}122.5 \\
127.4 \\
120.0 \\
117.0\end{array}$ & $\begin{array}{l}26.0 \\
21.0 \\
25.0 \\
23.5\end{array}$ & $\begin{array}{l}-2.89 \\
-2.24 \\
-2.70 \\
-1.45\end{array}$ & $\begin{array}{c}<0.01 \\
<0.05 \\
<0.05 \\
\text { NS }\end{array}$ \\
\hline FTI & $\begin{array}{l}A \\
B \\
C \\
D\end{array}$ & $\begin{array}{l}35 \\
25 \\
24 \\
26\end{array}$ & $\begin{array}{l}2.62 \\
2.82 \\
2.38 \\
2.55\end{array}$ & $\begin{array}{l}0.43 \\
0.46 \\
0.45 \\
0.46\end{array}$ & $\begin{array}{l}2.78 \\
3.08 \\
2.66 \\
2.78\end{array}$ & $\begin{array}{l}0.49 \\
0.44 \\
0.56 \\
0.62\end{array}$ & $\begin{array}{l}-2.62 \\
-2.48 \\
-2.39 \\
-2.35\end{array}$ & $\begin{array}{l}<0.05 \\
<0.05 \\
<0.05 \\
<0.05\end{array}$ \\
\hline $\mathrm{T}_{3}(\mathrm{nmol} / \mathrm{l})$ & $\begin{array}{l}\text { A } \\
B \\
C \\
D\end{array}$ & $\begin{array}{l}35 \\
25 \\
24 \\
26\end{array}$ & $\begin{array}{l}1.89 \\
1.93 \\
1.77 \\
1.74\end{array}$ & $\begin{array}{l}0.46 \\
0.26 \\
0.28 \\
0.28\end{array}$ & $\begin{array}{l}1.86 \\
1.77 \\
1.88 \\
1.77\end{array}$ & $\begin{array}{l}0.45 \\
0.23 \\
0.34 \\
0.31\end{array}$ & $\begin{array}{r}0.30 \\
3.44 \\
-1.27 \\
-0.50\end{array}$ & $\begin{array}{c}\text { NS } \\
<0.01 \\
\text { NS } \\
\text { NS }\end{array}$ \\
\hline
\end{tabular}

NS, not significant. 
Table 2 Comparison of the lipid levels before and after thyroxine administration ( $t$-test for cholesterol, and Wilcoxon matched-pairs signed ranks test for triglycerides) in the four groups of patients.

\begin{tabular}{|c|c|c|c|c|c|c|c|c|}
\hline \multirow[b]{2}{*}{ Parameter } & \multirow[b]{2}{*}{ Group } & \multirow[b]{2}{*}{$n$} & \multicolumn{2}{|c|}{ Before } & \multicolumn{2}{|c|}{ After } & \multirow[b]{2}{*}{ t value } & \multirow{2}{*}{$\begin{array}{c}\text { Level of } \\
\text { significance }\end{array}$} \\
\hline & & & Mean & S.D. & Mean & S.D. & & \\
\hline Total cholesterol (nmol/l) & $\begin{array}{l}A \\
B \\
C \\
D\end{array}$ & $\begin{array}{l}35 \\
25 \\
24 \\
26\end{array}$ & $\begin{array}{l}8.97 \\
8.73 \\
8.52 \\
8.96\end{array}$ & $\begin{array}{l}1.00 \\
0.85 \\
0.92 \\
1.00\end{array}$ & $\begin{array}{l}8.70 \\
8.60 \\
8.50 \\
8.20\end{array}$ & $\begin{array}{l}1.32 \\
1.00 \\
1.20 \\
1.16\end{array}$ & $\begin{array}{l}1.39 \\
0.93 \\
0.16 \\
4.25\end{array}$ & $\begin{array}{c}\text { NS } \\
\text { NS } \\
\text { NS } \\
<0.01\end{array}$ \\
\hline $\mathrm{HDL}(\mathrm{nmol} / \mathrm{l})$ & $\begin{array}{l}A \\
B \\
C \\
D\end{array}$ & $\begin{array}{l}18 \\
25 \\
15 \\
16\end{array}$ & $\begin{array}{l}1.27 \\
1.32 \\
1.31 \\
1.29\end{array}$ & $\begin{array}{l}0.15 \\
0.19 \\
0.15 \\
1.19\end{array}$ & $\begin{array}{l}1.21 \\
1.39 \\
1.32 \\
1.30\end{array}$ & $\begin{array}{l}0.18 \\
0.20 \\
0.14 \\
0.14\end{array}$ & $\begin{array}{r}1.35 \\
-0.53 \\
-0.38 \\
-0.20\end{array}$ & $\begin{array}{l}\text { NS } \\
\text { NS } \\
\text { NS } \\
\text { NS }\end{array}$ \\
\hline LDL (nmol/l) & $\begin{array}{l}A \\
B \\
C \\
D\end{array}$ & $\begin{array}{l}18 \\
25 \\
15 \\
16\end{array}$ & $\begin{array}{l}6.04 \\
6.50 \\
6.20 \\
6.80\end{array}$ & $\begin{array}{l}0.68 \\
0.83 \\
0.79 \\
1.05\end{array}$ & $\begin{array}{l}5.8 \\
6.4 \\
6.1 \\
5.9\end{array}$ & $\begin{array}{l}1.40 \\
1.04 \\
1.17 \\
1.00\end{array}$ & $\begin{array}{l}1.32 \\
0.60 \\
0.18 \\
4.20\end{array}$ & $\begin{array}{l}\text { NS } \\
\text { NS } \\
\text { NS } \\
<0.01\end{array}$ \\
\hline Triglycerides (g/l) & $\begin{array}{l}\text { A } \\
B \\
C \\
D\end{array}$ & $\begin{array}{l}35 \\
25 \\
24 \\
26\end{array}$ & $\begin{array}{l}1.86 \\
1.42 \\
1.46 \\
1.50\end{array}$ & $\begin{array}{l}1.00 \\
0.59 \\
1.01 \\
0.92\end{array}$ & $\begin{array}{l}1.82 \\
1.27 \\
1.45 \\
1.44\end{array}$ & $\begin{array}{l}1.24 \\
0.70 \\
0.76 \\
0.89\end{array}$ & $\begin{array}{l}(-0.82)^{*} \\
(-2.46)^{*} \\
(-0.59)^{*} \\
(-0.42)^{*}\end{array}$ & $\begin{array}{c}\text { NS } \\
<0.05 \\
\text { NS } \\
\text { NS }\end{array}$ \\
\hline
\end{tabular}

NS, not significant.

${ }^{*} \mathrm{z}$ values are shown in parentheses, Wilcoxon test used.

levels were significantly decreased only in group D (Table 2).

Table 3 shows the mean changes in TSH values in the four groups which were more marked in group D. Variance analysis showed that the difference between the groups was statistically significant $(P<0.05)$.

Comparison of the changes of the various parameters in group D with the respective changes in the other groups (Mann-Whitney test), showed that the decrease in TSH levels was accompanied by a decrease in total cholesterol and LDL cholesterol levels. No changes in the patients' weight or in any of the other parameters assessed were observed.

Finally, the effect of the presence of thyroid autoantibodies on the outcome of treatment with thyroxine was examined. Total cholesterol did not respond to thyroxine treatment in the patients with negative ThAabs, while a decrease in LDL levels was observed in all subgroups (Table 4).

Table 3 Mean changes in the TSH values after thyroxine administration in the four groups of patients (variance analysis, Fisher's least significance difference). Asterisks indicate that the two groups differed significantly so far as the TSH decrease was concerned; group D showed a more marked decrease in TSH values.

\begin{tabular}{|c|c|c|c|c|c|}
\hline \multirow{2}{*}{$\begin{array}{l}\text { Mean change in } \\
\text { TSH value }\end{array}$} & \multirow[b]{2}{*}{ Group } & \multicolumn{4}{|c|}{ Group } \\
\hline & & $D$ & $\mathrm{C}$ & B & $A$ \\
\hline $\begin{array}{l}-1.36 \\
-0.63 \\
-0.28 \\
-0.17\end{array}$ & $\begin{array}{l}D \\
C \\
B \\
A\end{array}$ & $\begin{array}{l}* \\
* \\
*\end{array}$ & * & & \\
\hline
\end{tabular}

The percentage of patients having positive ThAabs was significantly different between groups with low-normal TSH (A and B) and the groups with high-normal TSH (C and D): anti-TPO: $15 / 60$ vs $25 / 50, \chi^{2}=7.4, P<0.01$; anti-Tg: $5 / 60$ vs $15 / 50, \chi^{2}=21.4, P<0.01$, in the lownormal and the high-normal TSH groups respectively. Similarly the percentage of patients having both ThAabs positive was significantly higher in the high-normal TSH group $(13 / 36)$ than in the low-normal TSH group (1/42), $\chi^{2}=15, P<0.01$.

\section{Discussion}

It has often been reported that patients with subclinical hypothyroidism have lipid abnormalities $(6-8,12)$. We have previously shown that in a population with high cholesterol levels there was an increased proportion of subjects with clinical and subclinical hypothyroidism; furthermore in the same population there was an increased proportion of patients with $\mathrm{TSH}$ values between $2-4 \mu \mathrm{U} / \mathrm{ml}$ (9). The conclusion from that study was that the group of individuals with elevated cholesterol levels may, in fact, include patients with a mild form of subclinical hypothyroidism.

Several studies have shown that $\mathrm{T}_{4}$ administration to the group of subjects with subclinical hypothyroidism was accompanied by a significant lowering of cholesterol levels (10, 13-16). Our study, which focused on a different group of patients i.e. hypercholesterolemic patients presenting with TSH levels in the high-normal range, showed that these patients too may benefit from $\mathrm{T}_{4}$ administration. This observation raises the interesting possibility that even the stage preceding the so called 'subclinical' hypothyroidism may be associated with 
Table 4 Comparison of total cholesterol and LDL levels before and after thyroxine administration in the four groups of patients according to the presence of autoantibodies.

\begin{tabular}{lllllc}
\hline & & \multicolumn{4}{c}{ Group } \\
\cline { 3 - 6 } Parameter & Antibody & A & B & C & D \\
\hline Total cholesterol & Anti-TPO -ve & NS & NS & NS & NS \\
& Anti-TPO +ve & NS & NS & NS & $*$ \\
& Anti-Tg - ve & NS & NS & NS & NS \\
LDL & Anti-Tg +ve & NS & NS & NS & $*$ \\
& Anti-TPO -ve & NS & NS & NS & $*$ \\
& Anti-TPO +ve & NS & NS & NS & $*$ \\
& Anti-Tg -ve & NS & NS & NS & $*$ \\
& Anti-Tg +ve & NS & NS & NS & $*$ \\
\hline
\end{tabular}

Asterisks indicate significant decrease $(P<0.05, t$-test $)$. NS, not significant.

lipid abnormalities and that this group may not in fact be as 'normal' as previously thought. Thyroxine administration was accompanied by a significant lowering of cholesterol and LDL cholesterol levels in this group. The fact that this effect was only observed in antibody-positive patients supports the view that they already have a subtle thyroid dysfunction, presenting with elevated cholesterol levels. In population studies it has been reported that a rise in TSH levels above $2 \mu \mathrm{U} / \mathrm{ml}$ is associated with an increased probability of progression to clinical hypothyroidism and that this probability is further increased by the presence of thyroid autoantibodies $(4,17)$. All these observations suggest that hypothyroidism may be a graded phenomenon, and that there probably is a continuum from the perfectly euthyroid status to subclinical and clinical hypothyroidism. To define the degree of the dysfunction, apart from TSH measurement, one may have to include the determination of autoantibodies and cholesterol levels. Determination of thyroid autoantibodies will also discriminate other, more rare, causes for an elevated TSH, such as recovery from non-thyroid illness, previous ${ }^{131}$ I administration, iodine deficiency or iodine excess or, more rarely, thyroid hormone or TSH resistant states.

These individuals have so far been considered as 'normal'. As subclinical hypothyroidism is a common disorder (found in approximately $7-10 \%$ of adults $(1,18)$ ), it is possible that when the reference range of TSH values is established in a laboratory from a group of random subjects considered healthy, this may in fact comprise a small percentage of symptomless individuals who have a subtle thyroid abnormality. This subgroup may also have evidence of early biochemical abnormalities of thyroid function at the tissue level such as elevated cholesterol. In this respect it is of interest that we recently observed an impairment of indices of endothelial function, which is an early sign for the development of atherosclerosis, in a similar group of 'healthy' individuals with TSH in the high-normal range (19).

One point that should be discussed is the fact that in the group with high-normal TSH levels where $25 \mu \mathrm{g}$ thyroxine was given, cholesterol levels did not improve. The TSH change was smaller in this group; it is therefore possible that if the observation period were longer, an analogous change would have been observed in this group too.

Some individuals with elevated TSH do not lower their cholesterol levels after treatment with $\mathrm{T}_{4}$ indicating that there may exist two different kinds of patients in this group, as proposed by Kabadi (20), the non-responders probably corresponding to those with a 'reset thyrostat' (20) and the responders having true subclinical disease. These individuals may be recognised using the criteria mentioned above.

We conclude that subjects with high-normal TSH levels combined with positive ThAab may, in fact, have subclinical hypothyroidism due to autoimmune thyroiditis presenting with elevated cholesterol levels. It is possible that these patients might benefit from thyroxine administration, although larger studies will be required before this can be recommended.

\section{References}

1 Sawin CT, Castelli WP, Hershman JM, McNamara P \& Bacharach P. The aging thyroid: thyroid deficiency in the Framingham study. Archives of Internal Medicine 1985145 1386-1388.

2 Cooper DS, Halpern R, Wood LC, Levin AA \& Ridgway EC. L-Thyroxine therapy in subclinical hypothyroidism: a doubleblind, placebo-controlled trial. Annals of Internal Medicine 1984 $10118-24$.

3 Nystrom F, Caidahl K, Fager G, Nikkelso C, Lundberg PA \& Lindstedt G. A double-blind cross-over 12-month study of L-thyroxine treatment of women with 'subclinical' hypothyroidism. Clinical Endocrinology 198829 63-75.

4 Vanderpump MPJ, Tunbridge WNG, French JM, Appleton D, Bates D, Clark F et al. The incidence of thyroid disorders in the community: a twenty-year follow-up of the Wickham survey. Clinical Endocrinology 199543 55-68.

5 Weetman AP. Hypothyroidism: screening and subclinical disease. British Medical Journal 1997314 1175-1178.

6 Fowler PBS, Swale J \& Andrews H. Hypercholesterolaemia in borderline hypothyroidism, stage of premyxoedema. Lancet 1970 ii $488-491$. 
7 Althaus BU, Staub J-J, Ryff De Leche A, Oberhanslie A \& Stahelin HB. LDL/HDL changes in subclinical hypothyroidism: possible risk factors for coronary heart disease. Clinical Endocrinology 198828 157-163.

8 Arem R \& Patsch W. Lipoprotein and apolipoprotein levels in subclinical hypothyroidism: effect of levothyroxine therapy. Archives of Internal Medicine 1990150 2097-2100.

9 Pallas D, Koutras DA, Adamopoulos P, Marafelia P, Souvatzoglou A, Piperingos G et al. Increased mean serum TSH in apparently euthyroid hypercholesterolemic patients. Does it mean occult hypothyroidism? Journal of Endocrinological Investigation 199114 $743-746$.

10 Tanis BC, Westendorp RGI \& Smelt AHM. Effect of thyroid substitution on hypercholesterolemia in patients with subclinical hypothyroidism: a reanalysis of intervention studies. Clinical Endocrinology 199644 643-649.

11 Mantzos J \& Yialouris PP. A simple and reproducible method for the estimation of tri-iodothyronine uptake (thyroxine binding index) using a new absorbent. Clinical Biochemistry 199215 76-79.

12 Ball MS, Griffiths D \& Thorogood M. Asymptomatic hypothyroidism and hypercholesterolaemia. Journal of the Royal Society of Medicine 199184 527-529.

13 Kutty KM, Bryant DG \& Farid NR. Serum lipids in hypothyroidism. A re-evaluation. Journal of Clinical Endocrinology and Metabolism $19784655-60$.

14 Glueck CJ, Lang J, Tracy T \& Speirs J. The common finding of overt hypothyroidism at initial clinical evaluation for hyperlipoproteinemia. Clinica Chimica Acta 1991201 113-122.
15 Staub JJ, Althaus BU, Engler H, Ryff AS, Trabucco P \& Marquardt K. Spectrum of subclinical and overt hypothyroidism: effect on thyrotropin, prolactin, and thyroid reserve, and metabolic impact on peripheral target tissues. American Journal of Medicine 199292 631-642.

16 Johnston J, McLelland A \& O'Reilly SJ. The relationship between serum cholesterol and serum thyroid hormones in male patients with suspected hypothyroidism. Annals of Clinical Biochemistry $199330256-259$.

17 Geul KW, Van Sluisveld ILL, Grabbee DE, Docter R, Bruyn AM, Hooykaas $\mathrm{H}$ et al. The importance of thyroid microsomal antibodies in the development of elevated serum TSH in middle aged women: associations with serum lipids. Clinical Endocrinology $199339275-280$.

18 Helfand M \& Crapo LM Screening for thyroid disease. Annals of Internal Medicine 1990112 840-849.

19 Lekakis J, Papamichael C, Alevizaki M, Piperingos G, Marafelia P, Mantzos J et al. Flow-mediated, endothelium-dependent vasodilatation is impaired in subjects with hypothyroidism, borderline hypothyroidism and high-normal serum TSH values. Thyroid 19977 411-414.

20 Kabadi UD. Subclinical hypothyroidism. Natural course of the syndrome during a prolonged follow-up study. Archives of Internal Medicine 1993153 957-961.

Received 6 June 1997

Accepted 29 September 1997 